\title{
Efficient direct shoot organogenesis and genetic stability in micropropagated sacha inchi (Plukenetia volubilis L.)
}

\author{
Catalina Restrepo-Osorio, Alejandro Gil-Correal, Lina Chamorro-Gutiérrez, Viviana Ramírez-Ríos, \\ Javier C. Álvarez and Diego Villanueva-Mejía* (i)
}

\begin{abstract}
Objective: It is necessary to improve biotech platforms based on in vitro cell tissue culture to support sacha inchi (Plukenetia volubilis L.) research programs and draw on the nutritional value of the high polyunsaturated fatty acid content of its oilseed. Here, we developed a rapid and efficient method for induction and direct in vitro shoot development for this species.

Results: Shoots were generated from hypocotyl explants. The highest organogenic response was obtained in woody plant medium supplemented with $1 \mathrm{mg} / \mathrm{L}$ thidiazuron and $0.5 \mathrm{mg} / \mathrm{L}$ zeatin supplemented with L-glutamine, adenine hemisulfate, and L-arginine. Shoots obtained using this medium were transferred and subcultivated with different concentrations of indole-3-butyric acid and 1-naphthylacetic acid for rooting. For the first time, a histological analysis was performed supporting direct organogenic development in this species. The plantlets obtained were transferred ex vitro with a survival percentage of $80 \%$. The genetic stability of the plants recovered was confirmed by randomly amplified polymorphic DNA analysis. All results indicate that it would be possible to stimulate direct shoot formation from hypocotyls to support the sustainable use of this species.
\end{abstract}

Keywords: Adventitious shoots, Rooting, Acclimatization, Oilseed, Tissue culture

\section{Introduction}

Sacha inchi (Plukenetia volubilis L.) is a perennial, woody, oleaginous climbing plant belonging to the Euphorbiaceae family [1] that is native to the rainforest of South America. This crop grows in disturbed wet lowland forest at elevations of up to $900 \mathrm{~m}$ in the Lesser Antilles and Surinam, and along the northern and western edge of the Amazon basin in Venezuela (Amazonas), Colombia, Ecuador, Peru, Bolivia, and Brazil (western Amazonas) [2]. Its oilseed has excellent nutritional value due to its high content of polyunsaturated fatty acids, including a-linolenic $(\mathrm{C} 18: 3, \omega-3)$ and linoleic $(\mathrm{C} 18: 2, \omega-6)$ acids

*Correspondence: dvillanu@eafit.edu.co

Department of Biological Sciences, CIBIOP Research Group, Universidad EAFIT, Medellín, Colombia
[3], which are essential components of the human diet and help to prevent coronary heart disease and hypertension [4].

Several scientific reports have focused on regeneration from hypocotyls and epicotyls in the Euphorbiaceae family $[5,6]$, despite high recalcitrance. Regarding sacha inchi specifically, a few studies have reported the use of in vitro propagation to evaluate the auxin:cytokinin ratio in apical meristems [7] and different segments of the epicotyl and hypocotyl [8-10], with highest shooting but low process efficiency with 0.5 and $1 \mathrm{mg} / \mathrm{L} 6$-benzylaminopurine and $0.1 \mathrm{mg} / \mathrm{L}$ and $0.25 \mathrm{mg} / \mathrm{L}$ 1-naphthylacetic acid (NAA). Therefore, it is imperative that scientific knowledge regarding in vitro establishment and effective propagation methods for this promising species is expanded as demand for its oilseed has recently increased 
worldwide. Such a science-based approach could support research programs on topics such as metabolite production by cell suspension [11] and genetic improvement using modern techniques that seek to overcome the issues of biotic and abiotic stress and enhance crop productivity and fatty acid content [12]. Here, a de novo organogenesis process was induced in sacha inchi and the response of hypocotyl segments under in vitro conditions was evaluated. Furthermore, histological analysis of direct shoot organogenesis was reported for the first time in this species, meaning that this scientific report represents one of the first significant advances in the micropropagation of sacha inchi.

\section{Main text}

\section{Materials and methods}

\section{Plant material and culture initiation}

Mature sacha inchi fruits were collected at Santa Rosa de Osos (N6 $32^{\prime} 42.5^{\prime \prime}$; W075 $\left.13^{\prime} 49.6^{\prime \prime}\right)$, Antioquia, Colombia, under a permit issued by the National Authority for Environmental Licenses (ANLA; resolution 1312 of 2015). Once transferred to the Plant Biotechnology Laboratory at Universidad EAFIT, the seed coats were removed, then the seeds were washed with soapy water, hydrated in a humid chamber for $12 \mathrm{~h}$, disinfected using $2 \mathrm{ml} / \mathrm{L}$ Timorex Gold $^{\circledR} 3 \mathrm{~h}$, and incubated in $50 \mathrm{mg} / \mathrm{L}$ vancomycin and $250 \mathrm{mg} / \mathrm{L}$ cefotaxime for $4 \mathrm{~h}$. Afterward, seeds were rinsed with $70 \%$ ethanol for $1 \mathrm{~min}$ and $2 \% \mathrm{v} / \mathrm{v}$ sodium hypochlorite for $10 \mathrm{~min}$. All steps included three sterile distilled water rinses. Next, seeds were cultured in woody plant medium (WPM) [13] supplemented with $30 \mathrm{~g} / \mathrm{L}$ sucrose and $2 \mathrm{~g} / \mathrm{L}$ activated charcoal and solidified with $1.8 \mathrm{~g} / \mathrm{L}$ phytagel ( $\mathrm{pH}$ 5.7). Seeds were maintained in total darkness for $30 \mathrm{~d}$ at $25 \pm 1{ }^{\circ} \mathrm{C}$ under a $12 \mathrm{~h}$ photoperiod with fluorescent white light lamps (TL5 14 W; Sylvania $^{\mathrm{TM}}$ ), under $32.43 \mu \mathrm{mol} / \mathrm{m}^{2}$ s luminous intensity. After $30 \mathrm{~d}$, germination rates were calculated.

\section{Induction of multiple shoots and regeneration of plantlets}

Once 2-week-old in vitro plantlets were obtained, hypocotyl sections were excised and placed in Petri dishes containing WPM supplemented with $0.5 \mathrm{mg} / \mathrm{L} \mathrm{CuSO}_{4}$ or $50 \mathrm{mg} / \mathrm{L} \mathrm{L}$-glutamine, adenine hemisulfate, and L-arginine $(\mathrm{G}+\mathrm{A}+\mathrm{A})$ (Table 1). Proximal and distal segments were taken from the hypocotyls to determine the effect of the cotyledonary node. Cytokinins [thidiazuron (TDZ), zeatin, $6-\gamma, \gamma$-dimethylallylamino purine, 6-benzylaminopurine, and kinetin] and auxins [indole3-butyric acid (IBA) and NAA] at concentrations of 0.5 and $1.0 \mathrm{mg} / \mathrm{L}$ were assessed. Control plants were grown without growth regulators. Three assays were performed at different times. Each experiment was performed on 15

Table 1 Effect of hypocotyl section (proximal or distal), supplements, and growth regulators on the total number of shoots, average shoots per explant, percentage of callus, and percentage of elongated shoots of $>2.5 \mathrm{~cm}$ of Plukenetia volubilis hypocotyls after $\mathbf{4 5} \mathrm{d}$ of cultivation

\begin{tabular}{|c|c|c|c|c|c|c|c|}
\hline \multirow[t]{2}{*}{ Components } & \multirow[t]{2}{*}{ Hormonal treatments } & \multicolumn{2}{|c|}{$\begin{array}{l}\text { Average of shoots } \\
\text { per explant }\end{array}$} & \multicolumn{2}{|c|}{ Percentage of callus } & \multicolumn{2}{|c|}{$\begin{array}{l}\text { Percentage } \\
\text { of elongated shoots } \\
(>2.5 \mathrm{~cm})\end{array}$} \\
\hline & & Proximal & Distal & Proximal & Distal & Proximal & Distal \\
\hline \multirow[t]{8}{*}{$\mathrm{CuSO}_{4}$} & TDZ (1 mg/L) & $3.04^{\mathrm{ab}}$ & $1.91^{b c}$ & $68.89^{\mathrm{a}}$ & $72.78^{\mathrm{a}}$ & $46.74^{\mathrm{a}}$ & $29.63^{\mathrm{a}}$ \\
\hline & TDZ (1 mg/L) + 2ip (0.5 mg/L) & $3.11^{\mathrm{ab}}$ & $1.73^{\mathrm{ab}}$ & $73.33^{\mathrm{a}}$ & $75.0^{\mathrm{a}}$ & $45.81^{\mathrm{a}}$ & $25.5^{\mathrm{a}}$ \\
\hline & TDZ (1 mg/L) + Zeatin $(0.5$ mg/L) & $4.62^{d}$ & $2.31^{\mathrm{c}}$ & $72.22^{\mathrm{a}}$ & $74.44^{\mathrm{a}}$ & $51.74^{\mathrm{ab}}$ & $37.96^{\mathrm{a}}$ \\
\hline & $\mathrm{TDZ}(1 \mathrm{mg} / \mathrm{L})+\mathrm{BAP}(0.5 \mathrm{mg} / \mathrm{L})$ & $3.93^{\mathrm{cd}}$ & $1.53^{\mathrm{ab}}$ & $76.11^{\mathrm{a}}$ & $77.78^{\mathrm{a}}$ & $48.54^{\mathrm{a}}$ & $26.67^{a}$ \\
\hline & TDZ (1 mg/L) + Kinetin (0.5 mg/L) & $3.51^{b c}$ & $1.62^{\mathrm{ab}}$ & $75.56^{\mathrm{a}}$ & $78.33^{\mathrm{a}}$ & $33.19^{a}$ & $28.52^{\mathrm{a}}$ \\
\hline & $\mathrm{TDZ}(1 \mathrm{mg} / \mathrm{L})+\mathrm{IBA}(0.5 \mathrm{mg} / \mathrm{L})$ & $3.42^{\mathrm{abc}}$ & $1.47^{\mathrm{ab}}$ & $75^{\mathrm{a}}$ & $75.56^{\mathrm{a}}$ & $41.33^{\mathrm{a}}$ & $26.67^{\mathrm{a}}$ \\
\hline & $\mathrm{TDZ}(1 \mathrm{mg} / \mathrm{L})+\mathrm{NAA}(0.5 \mathrm{mg} / \mathrm{L})$ & $3.36^{a b c}$ & $1.8^{\mathrm{b}}$ & $76.11^{\mathrm{a}}$ & $79.44^{\mathrm{a}}$ & $40.70^{\mathrm{a}}$ & $27.04^{a}$ \\
\hline & Control & $2.71^{\mathrm{a}}$ & $1.27^{\mathrm{a}}$ & $13.33^{b}$ & $11.11^{\mathrm{b}}$ & $69.26^{\mathrm{b}}$ & $68.52^{\mathrm{b}}$ \\
\hline \multirow[t]{8}{*}{$G+A+A$} & TDZ (1 mg/L) & $3.33^{\mathrm{abc}}$ & $1.76^{\mathrm{bc}}$ & $70^{\mathrm{b}}$ & $73.33^{\mathrm{a}}$ & $41.04^{\mathrm{ab}}$ & $30.37^{a}$ \\
\hline & TDZ (1 mg/L) + 2ip (0.5 mg/L) & $3.29^{\mathrm{ab}}$ & $1.8^{\mathrm{bc}}$ & $73.33^{b c}$ & $72.33^{\mathrm{a}}$ & $44.56^{\mathrm{ab}}$ & $27.41^{\mathrm{a}}$ \\
\hline & TDZ (1 mg/L) + Zeatin (0.5 mg/L) & $5.11^{\mathrm{e}}$ & $2.2^{c}$ & $73.89^{\mathrm{bc}}$ & $75.0^{\mathrm{a}}$ & $53.34^{\mathrm{b}}$ & $36.67^{a}$ \\
\hline & $\mathrm{TDZ}(1 \mathrm{mg} / \mathrm{L})+\mathrm{BAP}(0.5 \mathrm{mg} / \mathrm{L})$ & $4.87^{\mathrm{de}}$ & $1.62^{\mathrm{b}}$ & $76.11^{\mathrm{bc}}$ & $77.78^{\mathrm{a}}$ & $45.69^{\mathrm{ab}}$ & $29.63^{\mathrm{a}}$ \\
\hline & TDZ (1 mg/L) + Kinetin (0.5 mg/L) & $4.11^{c d}$ & $1.51^{\mathrm{ab}}$ & $76.07^{b c}$ & $76.67^{a}$ & $31.51^{\mathrm{a}}$ & $27.41^{\mathrm{a}}$ \\
\hline & $\mathrm{TDZ}(1 \mathrm{mg} / \mathrm{L})+\mathrm{IBA}(0.5 \mathrm{mg} / \mathrm{L})$ & $3.71^{a b c}$ & $1.6^{\mathrm{b}}$ & $78.33^{b c}$ & $76.11^{\mathrm{a}}$ & $45.70^{\mathrm{ab}}$ & $29.63^{a}$ \\
\hline & $\mathrm{TDZ}(1 \mathrm{mg} / \mathrm{L})+\mathrm{NAA}(0.5 \mathrm{mg} / \mathrm{L})$ & $3.93 b c$ & $1.73 \mathrm{bc}$ & $78.89^{c}$ & $80.0^{\mathrm{a}}$ & $38.56^{\mathrm{ab}}$ & $28.15^{\mathrm{a}}$ \\
\hline & Control & $3.0^{\mathrm{a}}$ & $1.09^{\mathrm{a}}$ & $14.44^{\mathrm{a}}$ & $11.11^{\mathrm{b}}$ & $77.26^{c}$ & $65.93^{b}$ \\
\hline
\end{tabular}

Different letters indicate significant differences $(p \leq 0.05)$ 
hypocotyl sections with three replications per treatment. After $45 \mathrm{~d}$, the callus percentage, the average number of shoots per explant, and the number of developed shoots were determined (Table 1).

\section{Histological observation}

Histological analysis was performed during the shoot formation process. Hypocotyl sections of $1 \mathrm{~cm}$ in length with meristematic growth zones were set in a mixture of formaldehyde, ethanol, and acetic acid for $24-48 \mathrm{~h}$ at $6{ }^{\circ} \mathrm{C}$, and dehydrated in a graduated alcohol series $(70 \%$, $80 \%, 90 \%, 95 \%$, and $100 \%$ ). Two lightning steps in xylenes were carried out ( $4 \mathrm{~h}$ each step) and the hypocotyl sections were submerged in Paraplast Plus for $12 \mathrm{~h}$ at $55^{\circ} \mathrm{C}$. Longitudinal Sects. (5-7 $\mu \mathrm{m}$ thick) were cut from the hypocotyls using a Spencer $820^{\circledR}$ rotary microtome and stained with Safranin O and Alcian blue staining solution to highlight the primary and secondary walls, respectively. Some sections were stained with Amido Black staining solution $2 \times$ and toluidine blue $\mathrm{O}$ for additional visualization. All samples were examined using a photonic microscope.

\section{Rooting and plant acclimatization}

Once shoots reached $3 \mathrm{~cm}$ in length, they were separated from the explants and planted in WPM with IBA and NAA (two concentrations). Control experiments were also set up without growth regulators. In the fourth week, the number of rooted plants and the average number of roots per plant were estimated. Plants $6 \mathrm{~cm}$ in height with roots were removed from the medium, washed with abundant water, and transferred to individual pots $(9 \times 10 \mathrm{~cm})$ in a mixture of peat moss and sand (3:1) that had previously been sterilized. Pots were transferred to a greenhouse and covered with perforated plastic glass for $20 \mathrm{~d}$. Every $4 \mathrm{~d}$, the substrate was moistened, and every week it was fertilized with WPM basal salts, Murashige and Skoog [14] basal salts, or just water. On the 30th day, the survival percentage was estimated. On the 60th day, plant height, the number of leaves, shoots, roots, and survival percentages were assessed.

\section{DNA extraction and RAPD amplification}

The clonal fidelity of in vitro-raised plants was tested using RAPD markers. DNA was extracted using the cetyltrimethylammonium bromide (CTAB) method [15] and the DNA quality and quantity was verified on agarose gel using a Nanodrop 2000 spectrophotometer. Fifteen RAPD primers were used under the conditions reported by Gajera et al. [16]. Each experiment was repeated three times, and reproducible DNA bands were considered for data analysis. The presence (1) or absence (0) of fragments was manually scored in a binary data matrix. Amplified fragments were analyzed as alleles, assuming Hardy-Weinberg equilibrium and loci segregation in a dominant Mendelian fashion. We used Jaccard's coefficient of similarity $[\mathrm{Jij}=\mathrm{a} /(\mathrm{a}+\mathrm{b}+\mathrm{c})]$ to compute the binary datasets [17].

\section{Statistical analysis}

Data normality was investigated [18] and differences between pairs of groups were evaluated using the T-test. Differences between more than two groups were evaluated [19] using analysis of variance (ANOVA) for parametric data and the Kruskal-Wallis test [19] for nonparametric distributions followed by the pairwise Wilcoxon rank-sum [20] or the Tukey HSD test, respectively, when at least one different group was found $(\alpha<0.05)$. All statistical analyses were performed using R 3.4.2 software [21].

\section{Results and discussion \\ Culture initiation and histological analysis}

Due to high seed contamination (35.6\%) and a low germination rate $(34.4 \%)$ (Fig. 1a), mature zygotic embryo rescue was necessary (Fig. 1b), which led to an increase in the germination rate to $71.7 \%$. Hypocotyl segments selected as explants from 3-week-old plantlets (Fig. 1a) developed calluses after $8 \mathrm{~d}$ of culture (Fig. 1c). After 20 $\mathrm{d}$, adventitious shoots appeared in all treatment groups, including the control (Fig. 1d-e). All segments treated with growth regulators developed calluses, and histological analysis indicated a connection between maternal tissue and induced shoots not from the callus, which is characteristic of the organogenic process and demonstrates organogenic growth (Fig. 1f-h). The central part of the nodular structure was mainly surrounded by parenchyma, cambium, and tracheal elements (Fig. 1h). The connection zone between the hypocotyl and the nodular structure presented small cells with huge periclinal and anticlinal divisions, massive cores, and dense cytoplasm (Fig. 1f-h); meanwhile, the epidermal and subepidermal layers comprised cells that were divided and more intensely stained. The formation of meristematic areas from differentiated cells occurred due to the proximity of differentiated cells to existent meristematic tissues, where growth regulators were assumed to be highly concentrated [22].

\section{Shoot induction and regeneration of plantlets}

Shoot induction from hypocotyl segments depended on the position (proximal/distal) relative to the cotyledonary 


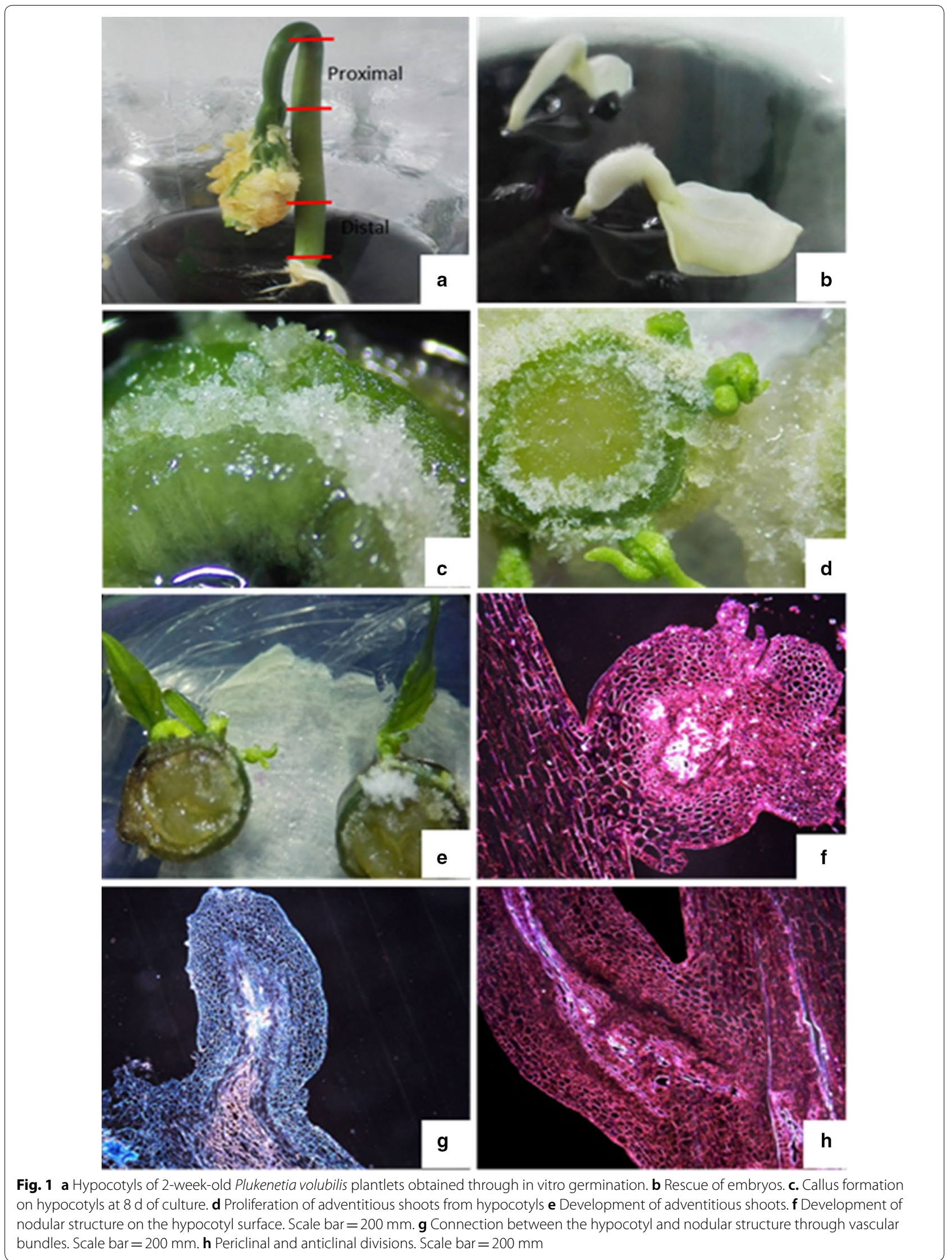


node (Table 1). A higher number of induced shoots were observed closer to the cotyledonary node, as previously reported in Jatropha curcas [5] and Euonymus japonicus [23]. Shoot number gradually and significantly decreased $(\mathrm{p} \leq 0.05)$ with distance from the cotyledonary node, possibly due to the lower level of endogenous growth regulators further from the node.

Although severe adventitious shoot formation was observed at all concentrations of growth regulators, a more significant rate (5.1 shoots per hypocotyl proximal section) was observed in medium containing $1 \mathrm{mg} / \mathrm{L} \mathrm{TDZ}$ and $0.5 \mathrm{mg} / \mathrm{L}$ zeatin and supplemented with $\mathrm{G}+\mathrm{A}+\mathrm{A}$. Meanwhile, the lowest adventitious shoot formation rate was obtained for the control medium supplemented with $\mathrm{CuSO}_{4}$ and $\mathrm{G}+\mathrm{A}+\mathrm{A}$. In the hypocotyl distal section, the average number of shoots per explant was comparable at all growth regulator concentrations, with no significant differences between treatments $(\mathrm{p} \leq 0.05)$. Cytokinins, particularly TDZ, are hormones that directly or indirectly stimulate organogenesis, promoting de novo shoot regeneration in herbaceous [24] and woody plants [25]. In species from the Euphorbiaceae family, such as J. curcas and Ricinus communis, TDZ has been reported to induce the formation of adventitious shoots from hypocotyls $[5,26]$.

\section{Rooting and acclimatization}

The number of rooted plants was highest on the 45th day, with the highest percentage of rooted plants (91.1\%) in $1 \mathrm{mg} / \mathrm{L}$ IBA and the lowest (48.9\%) in the control medium $(\mathrm{p} \leq 0.05)$ (Table S1). Root formation occurred in all treatment groups, probably due to the endogenous concentration of auxins or activated charcoal supplements, which produce ideal conditions for root development in plants [27]. IBA has been extensively used to induce rooting in different species under in vitro conditions, with optimum results at low concentrations [28]. In Euphorbiaceae, IBA has been reported to induce rooting at low concentrations in J. curcas $(0.2 \mathrm{mg} / \mathrm{L} \mathrm{IBA})$ [29] and $R$. communis (1 mg/L IBA) [26], although other species require high IBA concentrations $(3.0 \mathrm{mg} / \mathrm{L})$ [30].

Plants with well-developed roots were transplanted to a greenhouse in which the humidity and luminous intensity were semi-controlled. There, sacha inchi plants showed excellent acclimatization, with a survival percentage of $>80 \%$. After 2 months, plants treated with WPM nutrients reached $7.96 \mathrm{~cm}$ in height (Table 2). The peat moss used as substrate probably played a considerable role in minimizing hydric stress in hardened plants. At the end of the process, the regenerated plants showed no signs of morphological abnormalities.

\section{RAPD analysis}

RAPD analysis has been widely used to characterize somaclonal variation in plantlets in vitro because it is affordable and useful for detecting variations in vegetable crops [31]. In the present study, the RAPD markers OPD08 and OPA-13 allowed the amplification of 17 fragments from all genotypes analyzed, with sizes between 250 and $4000 \mathrm{bp}$. Only three fragments, obtained with the primer OPA-13, were polymorphic; these fragments exhibited insignificant genetic variability between mother and daughter plants, confirming the genetic stability of the sacha inchi plantlets generated through direct in vitro organogenesis from hypocotyls. Similar results were previously obtained in Musa acuminata [32] and Solanum melongena L.[33], which were regenerated from hypocotyls with no evidence of polymorphic bands in RAPD analysis. According to Jaccard's coefficient of similarity, the plants regenerated via organogenesis in the present study had $89 \%$ genetic similarity to mother hypocotyls (Table S2), indicating that the micropropagation procedure reliably maintained the genetic stability of plant material.

\section{Limitations}

Further work needs to be done to establish genetic stability using additional molecular markers (e.g., microsatellites) or, ideally, flow cytometry. This research did not examine in detail the role played by parameters such as age, cultivar genotype, and the concentrations of plant growth regulators on regeneration efficiency.

Table 2 Survival percentage, average height, and number of leaves, roots, and shoots of Plukenetia volubilis plants germinated in vitro at $60 \mathrm{~d}$ of hardening

\begin{tabular}{lllll}
\hline Media treatments & Survival (\%) & Average height $(\mathbf{c m})$ & \# Average leaves & \# Average roots \\
\hline WPM & $86.67^{\mathrm{a}}$ & $7.96^{\mathrm{a}}$ & $4.4^{\mathrm{a}}$ & $2.38^{\mathrm{a}}$ \\
MS & $82.22^{\mathrm{a}}$ & $6.69^{\mathrm{b}}$ & $3.29^{\mathrm{b}}$ & $1.2^{\mathrm{b}}$ \\
Control & $84.44^{\mathrm{a}}$ & $4.38^{\mathrm{c}}$ & $2.18^{\mathrm{c}}$ & $1.02^{\mathrm{b}}$
\end{tabular}

Different letters indicate significant differences $(p \leq 0.05)$ 


\section{Supplementary information}

Supplementary information accompanies this paper at https://doi. org/10.1186/s13104-020-05257-1.

Additional file 1: Table S1. Effect of auxins on the rooting of adventitious shoots in Plukenetia volubilis

Additional file 2: Table S2. Similarity coefficients among mother plants and micropropagated hypocotyls of Plukenetia volubilis based on RAPD markers.

\section{Abbreviations}

2ip: 6- $\gamma$, $\gamma$-Dimethylallylamino purine; ANLA: National Authority for Environmental licenses; BAP: 6-Benzylaminopurine; CTAB: Cetyltrimethylammonium bromide; $\mathrm{CuSO}_{4}$ : Cupric sulfate pentahydrate; $\mathrm{G}+\mathrm{A}+\mathrm{A}$ : I-Glutamine, adenine hemisulfate, and L-arginine; IBA: Indole-3-butyric acid; NAA: 1-Naphthylacetic acid; MS: Murashige and Skoog; RAPD: Random amplification of polymorphic DNA; TDZ: Thidiazuron; WPM: Woody plant medium.

\section{Acknowledgements}

The authors would like to thank SGR system, Secretaría de Agricultura y Desarrollo Rural del Departamento de Antioquia, Universidad Pontificia Bolivariana, Universidad Nacional de Colombia and Universidad EAFIT.

\section{Authors' contributions}

CRO and AGC were the researchers who contributed to the design, implementation of the experiments, and the analysis of results in the in vitro propagation of Sacha inchi. LCH was the lawyer in charge of carrying out all the legal procedures that are required before government entities to access the biological resource. VRR was the researcher in charge of the design, implementation of the experiments and the analysis of results in the analysis of genetic diversity of the Sacha inchi in vitro plants, JCA and DVM were the senior investigators of the research, conceived the global project and coordinated the activities carried out by researchers CRO, AGC, LCH, and VRR. All authors read and approved the final manuscript.

\section{Funding}

This work was supported by "Component No 1 - Biotechnology" project code 4600000480 financed by the Colombian general royalty system (SGR, Spanish acronym) and Secretaría de Agricultura y Desarrollo Rural del Departamento de Antioquia. The funding body had no role in study design, analysis of data, interpretation of data, and the decision to submit the article for publication.

\section{Availability of data and materials}

The datasets used and/or analyzed during the current study are available from the corresponding author on reasonable request.

\section{Ethics approval and consent to participate}

Not applicable.

\section{Consent for publication}

Not applicable.

\section{Competing interests}

All authors declare that they have no competing interests.

Received: 16 June 2020 Accepted: 26 August 2020

Published online: 03 September 2020

\section{References}

1. Gillespie LJ. A Synopsis of Neotropical Plukenetia (Euphorbiaceae) Including Two New Species. Syst Bot. 1993;18:575-92. https://www.jstor.org/ stable/2419535. Accessed 15 Sep 2017.

2. Jiménez Ramírez J, Martínez Gordillo M, Cruz DR. Genero Plukenetia (Euphorbiaceae) en México. Anales del Instituto de Biologia Nacional Autonoma de Mexico. 2000;71:11-8.
3. Gutiérrez L-F, Quiñones-Segura Y, Sanchez-Reinoso Z, Díaz DL, Abril Jl. Physicochemical properties of oils extracted from y-irradiated Sacha Inchi (Plukenetia volubilis L.) seeds. Food Chem. 2017;237:581-7. https://doi. org/10.1016/j.foodchem.2017.05.148.

4. Simopoulos AP. Evolutionary aspects of diet: the omega-6/omega-3 ratio and the brain. Mol Neurobiol. 2011;44:203-15. https://doi.org/10.1007/ s12035-010-8162-0.

5. Sharma S, Kumar N, Reddy MP. Regeneration in Jatropha curcas: factors affecting the efficiency of in vitro regeneration. Ind Crops Prod. 2011;34:943-51. https://doi.org/10.1016/j.indcrop.2011.02.017.

6. Gil-Correal A, Restrepo-Osorio C, Correa Álvarez J, Villanueva-Mejía DF. Direct in vitro regeneration of castor bean plants (Ricinus communis) using epicotyls. Biosci J. 2019;35:347-55.

7. Solis R, Cachique D, Guerrero-Abad JC, Sánchez MER. Tapia y Figueroa $\mathrm{L}$. In vitro propagation of sacha inchi through organogenesis. Pesqui Agropecuária Bras. 2018;53:1285-8.

8. Bordignonl S, Ambrosano G, Rodrigues P. Propagação in vitro de Sacha inchi. Ciência Rural St Maria. 2012;42:1168-72.

9. Viegas RP, Bordignon S, Bovi AG. Desempenho horticultural de plantas propagadas in vitro de Sacha inchi. Cienc Rural St Maria. 2014:44:1050-3.

10. Pilco Lozano RE. Uso de Tecnologías in-vitro en Sacha inchi (Plukenetia volubilis L). Czech University of Life Sciences Prague; 2014.

11. Schillberg S, Raven N, Fischer R, Twyman R, Schiermeyer A. Molecular farming of pharmaceutical proteins using plant suspension cell and tissue cultures. Curr Pharm Des. 2013;19:5531-42.

12. Francis D, Finer JJ, Grotewold E. Challenges and opportunities for improving food quality and nutrition through plant biotechnology. In: Current opinion in biotechnology. 2017. p. 124-9.

13. Lloyd G, McCown B. Commercially-feasible micropropagation of mountain laurel, Kalmia latifolia, by use of shoot-tip culture. Comb Proceedings, Int Plant Propagators' Soc. 1980;30:421-7. https://www. cabdirect.org/cabdirect/abstract/19830315515. Accessed 15 Sep 2017.

14. Murashige T, Skoog F. A revised medium for rapid growth and bio assays with tobacco tissue cultures. Physiol Plant. 1962;15:473-97. https://onlinelibrary.wiley.com/doi/abs/10.1111/j.1399-3054.1962. tb08052.x.

15. Murray MG, Thompson WF. Rapid isolation of high molecular weight plant DNA. Nucleic Acids Res. 1980;8:4321-5.

16. Gajera BB, Kumar N, Singh AS, Punvar BS, Ravikiran R, Subhash N, et al Assessment of genetic diversity in castor (Ricinus communis L.) using RAPD and ISSR markers. Ind Crops Prod. 2010:32:491-8.

17. Shekhar S, Bhowmik D, Basu A, Sahoo L. Direct shoot organogenesis from rhizomes of medicinal zingiber Alpinia calcarata Rosc. and evaluation of genetic stability by RAPD and ISSR markers. J Crop Sci Biotech. 2016;19:157-65.

18. Shapiro SS, Wilk MB. An analysis of variance test for normality (complete samples). Biometrika. 1965;52:591-611. https://doi.org/10.1093/biome $\mathrm{t} / 52.3-4.591$.

19. Kruskal WH, Wallis WA. Use of ranks in one-criterion variance analysis. J Am Stat Assoc. 1952:47:583. https://doi.org/10.2307/2280779.

20. Wilcoxon F. Individual Comparisons by Ranking Methods. Biometrics Bull. 1945;1:80-3. https://sci2s.ugr.es/keel/pdf/algorithm/articulo/wilcoxon19 45.pdf. Accessed 15 Sep 2017

21. R Core Team. R: A language and environment for statistical computing. 2014. https://www.r-project.org/. Accessed 15 Oct 2019.

22. Vasil V, Lu C-Y, Vasil IK. Histology of somatic embryogenesis in cultured immature embryos of maize (Zea mays L.). Protoplasma. 1985;127:1-8. https://doi.org/10.1007/BF01273696.

23. Shang A, Cai H, Yan X, Hu H, Zhao L, Zhao Q. Plant Regeneration from In Vitro Cultured Hypocotyl Explants of Euonymus japonicus Cu zhi. Agric Sci China. 2006:5:196-201.

24. Ramírez-Mosqueda M, Iglesias-Andreu LG. Indirect organogenesis and assessment of somaclonal variation in plantlets of Vanilla planifolia Jacks. Plant Cell Tissue Organ Cult. 2015;123.

25. Magyar-Tábori K, Dobránszki J, da Silva JAT, Bulley SM, Hudák I. The role of cytokinins in shoot organogenesis in apple. Plant Cell Tissue Organ Cult. 2010;101:251-67.

26. Ahn YJ, Vang L, McKeon TA, Chen GQ. High-frequency plant regeneration through adventitious shoot formation in castor (Ricinus communis L.). Vitr Cell Dev Biol - Plant. 2007:43:9-15. 
27. Pan MJ, Van Staden J. The use of charcoal in in vitro culture-A review. Plant Growth Regul. 1998;26:155-63.

28. Nagori R, Purohit SD. In vitro plantlet regeneration in Annona squamosa through direct shoot bud differentiation on hypocotyl segments. Sci Hortic (Amsterdam). 2004;99:89-988.

29. Datta MM, Mukherjee P, Ghosh B, Jha TB. In vitro clonal propagation of biodiesel plant (Jatropha curcas L.). Curr Sci. 2007;93:1438-42.

30. Verma P, Mathur AK. Direct shoot bud organogenesis and plant regeneration from pre-plasmolysed leaf explants in Catharanthus roseus. Plant Cell Tissue Organ Cult. 2011;106:401-8.

31. Manuela de França Bettencourt G, Ricardo Soccol C, Salete Giovanella T, Franciscon L, Rigoni Kestring D, Rodrigues Gerhardt I, et al. Agrobacterium tumefaciens-mediated transformation of Eucalyptus urophylla clone BRS07-01. J For Res. 2020;31:507-19. https://doi.org/10.1007/s1167 6-018-0777-4
32. El-Mahdy MT, Youssef M. Genetic homogeneity and high shoot proliferation in banana (Musa acuminata Colla) by altering medium thiamine level and sugar type. Vitr Cell Dev Biol - Plant. 2019;55:668-77.

33. Padma Mallaya N, Ravishankar GA. In vitro propagation and genetic fidelity study of plant regenerated from inverted hypocotyl explants of eggplant (Solanum melongena L.) cv. Arka Shirish. 3 Biotech. 2013;3:4552. https://doi.org/10.1007/s13205-012-0068-2.

\section{Publisher's Note}

Springer Nature remains neutral with regard to jurisdictional claims in published maps and institutional affiliations.
Ready to submit your research? Choose BMC and benefit from:

- fast, convenient online submission

- thorough peer review by experienced researchers in your field

- rapid publication on acceptance

- support for research data, including large and complex data types

- gold Open Access which fosters wider collaboration and increased citations

- maximum visibility for your research: over 100M website views per year

At BMC, research is always in progress.

Learn more biomedcentral.com/submissions 